\title{
Kite-like structures in the Nama Karoo of South Africa
}

Jaco van der Walt ${ }^{1, *} \&$ Marlize Lombard ${ }^{1}$

Desert kites are well documented in the Middle East, Near East, Arabia and Central Asia, but are much rarer elsewhere. Here, we present two newly discovered kites near Keimoes in South Africa that provide possible evidence for animal exploitation during the Later Stone Age.

\section{Introduction}

Desert kites are well-known archaeological features in the Middle East. Distributed over large geographic areas, they were probably not constructed simultaneously or as part of a continuous process (Crassard et al. 2015). Here we announce two such newly discovered sites (Keimoes $1 \& 2$ ), located $22 \mathrm{~km}$ north of Keimoes in the Northern Cape Province of South Africa (Figure 1) in the arid, landlocked Nama-Karoo Biome. The two sites are separated by a non-perennial stream, in an open, relatively flat landscape. Keimoes 1 is farther to the west and slightly higher than Keimoes 2 (Figure 1). Both sites were constructed upon a hard calcrete deposit with pockets of red aeolian Kalahari sand.

\section{Brief description of the kite-like structures}

Keimoes 1 is the smaller of the two sites, with five funnel-shaped features. The first funnel is an isolated structure with two arms converging on an enclosure. This is located $156 \mathrm{~m}$ north of four similar structures, which join to form a single funnel chain (Figure 2). This layout repeats itself at Keimoes 2, where an isolated structure is located $243 \mathrm{~m}$ to the north-east of six funnel-shaped structures (Figure 3). The length of the funnel arms at both sites varies, with the longest being $\sim 75 \mathrm{~m}$, and the shortest $\sim 38 \mathrm{~m}$. The arms converge into funnel tubes $\sim 1.2 \mathrm{~m}$ in width and $6-11 \mathrm{~m}$ in length, before apexing into relatively small enclosures $\sim 2 \mathrm{~m}$ in diameter.

All the kites were constructed, or rather shaped, by organising local dolerite boulders into funnel-shaped features. This method differs slightly according to the location and distance from the final convergence points/apex enclosures. The guiding arms-those most distant from the apex enclosures—comprise alignments of single, large and roughly packed stones, sometimes incorporating in-situ dolerite outcrops/boulders. The arm extremities have no visible vertical organisation, and are $\sim 0.2-0.3 \mathrm{~m}$ high (Figure 4 ). The walls become

1 Centre for Anthropological Research and Department of Anthropology and Development Studies, University of Johannesburg, P.O. Box 524, Auckland Park Campus, Johannesburg 2006, South Africa

* Author for correspondence (Email: jaco.heritage@gmail.com) 


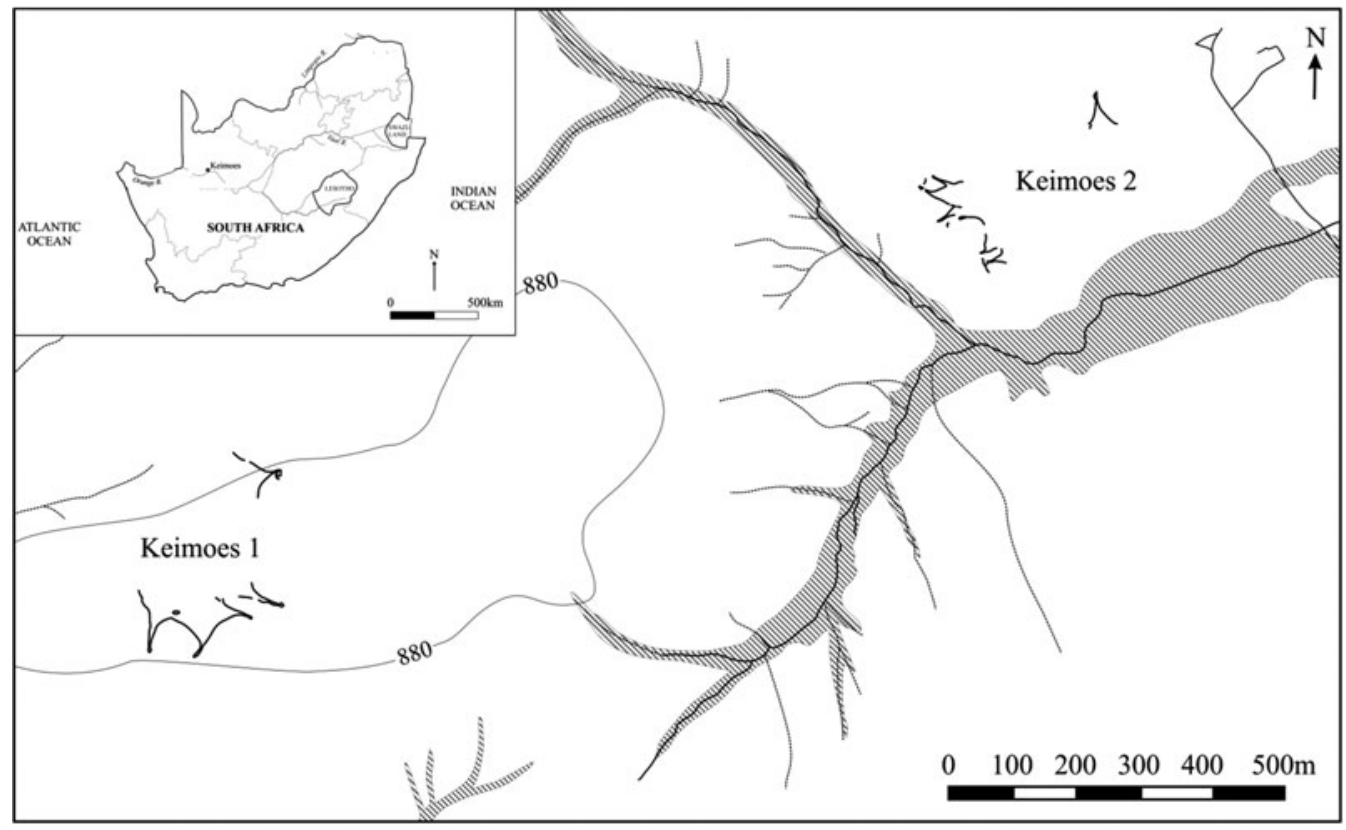

Figure 1. Map of South Africa showing Keimoes 1 and 2 (drawing: Wendy Voorvelt).
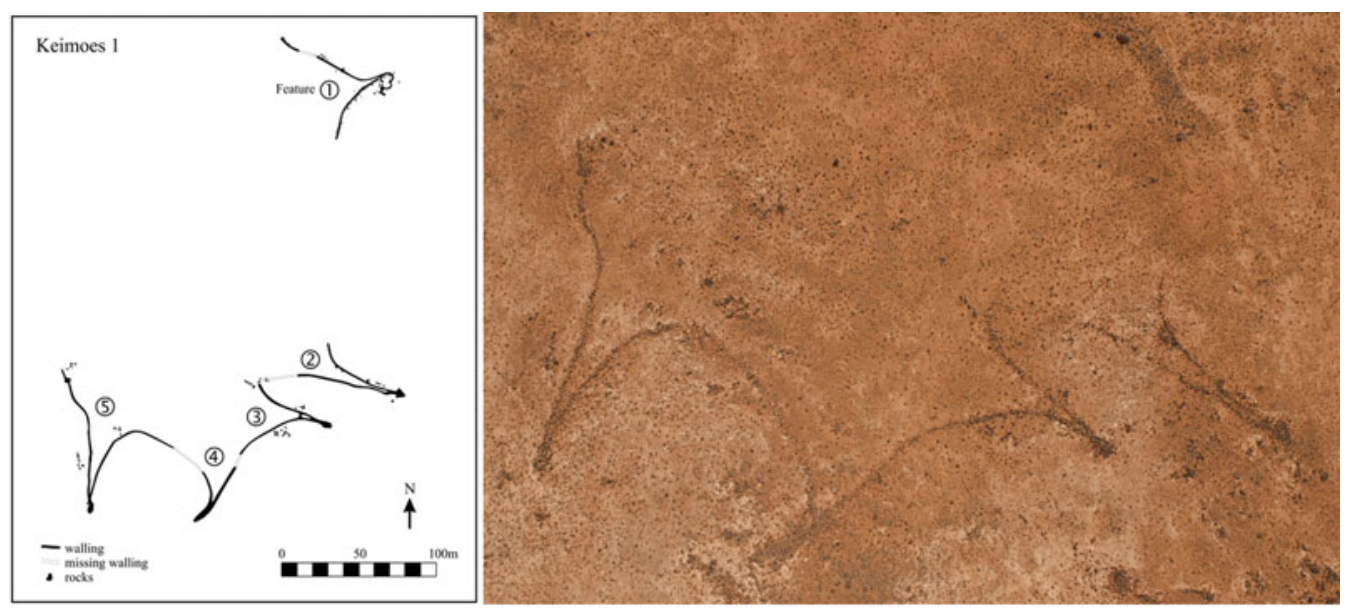

Figure 2. Site plan of Keimoes 1 on the left with aerial image of funnels 2-5 on the right (drawing: Wendy Voorvelt).

slightly higher closer to the apex enclosures, are more deliberately constructed and, in some instances, show vertical stacking. Funnel 3 at Keimoes 1, and funnel 1 at Keimoes 2, stonebuilt cells/corrals ( $\sim 4 \mathrm{~m}$ in diameter), are situated inside the kites and attached to both guiding arms before entering the funnel tube (Figure 5).

The Keimoes kite-like structures share characteristics with examples from the Negev (Israel) and Sinai (Egypt) Deserts (Figure 6), including general layout and isolated funnel-shaped structures. They are smaller than the larger, continuous chain-like (C) Antiquity Publications Ltd, 2018 
Keimoes 2

$$
\stackrel{N}{\uparrow}
$$

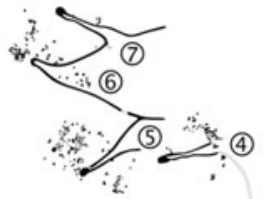

- walling
missing walling
rocks

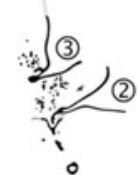<smiles>CCC(C)C</smiles>

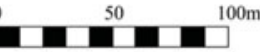

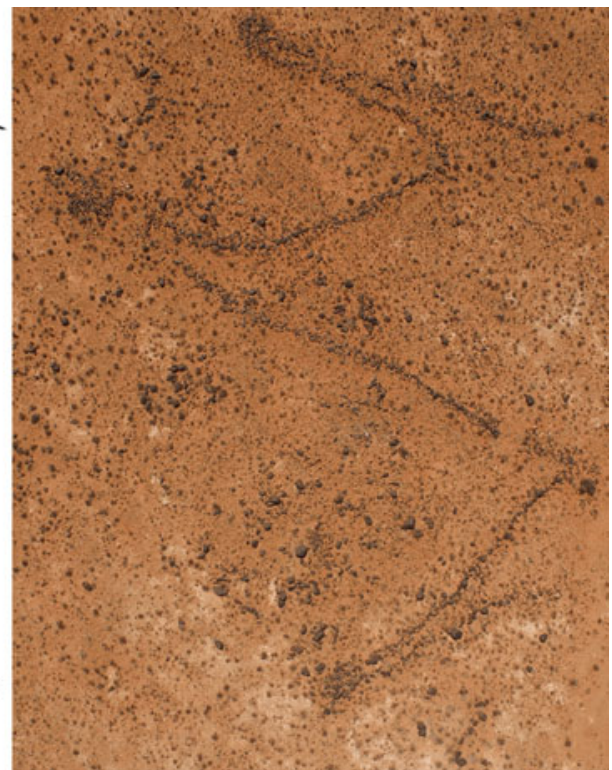

Figure 3. Site plan of Keimoes 2 on the left with aerial image of funnels 5-7 on the right (drawing: Wendy Voorvelt).

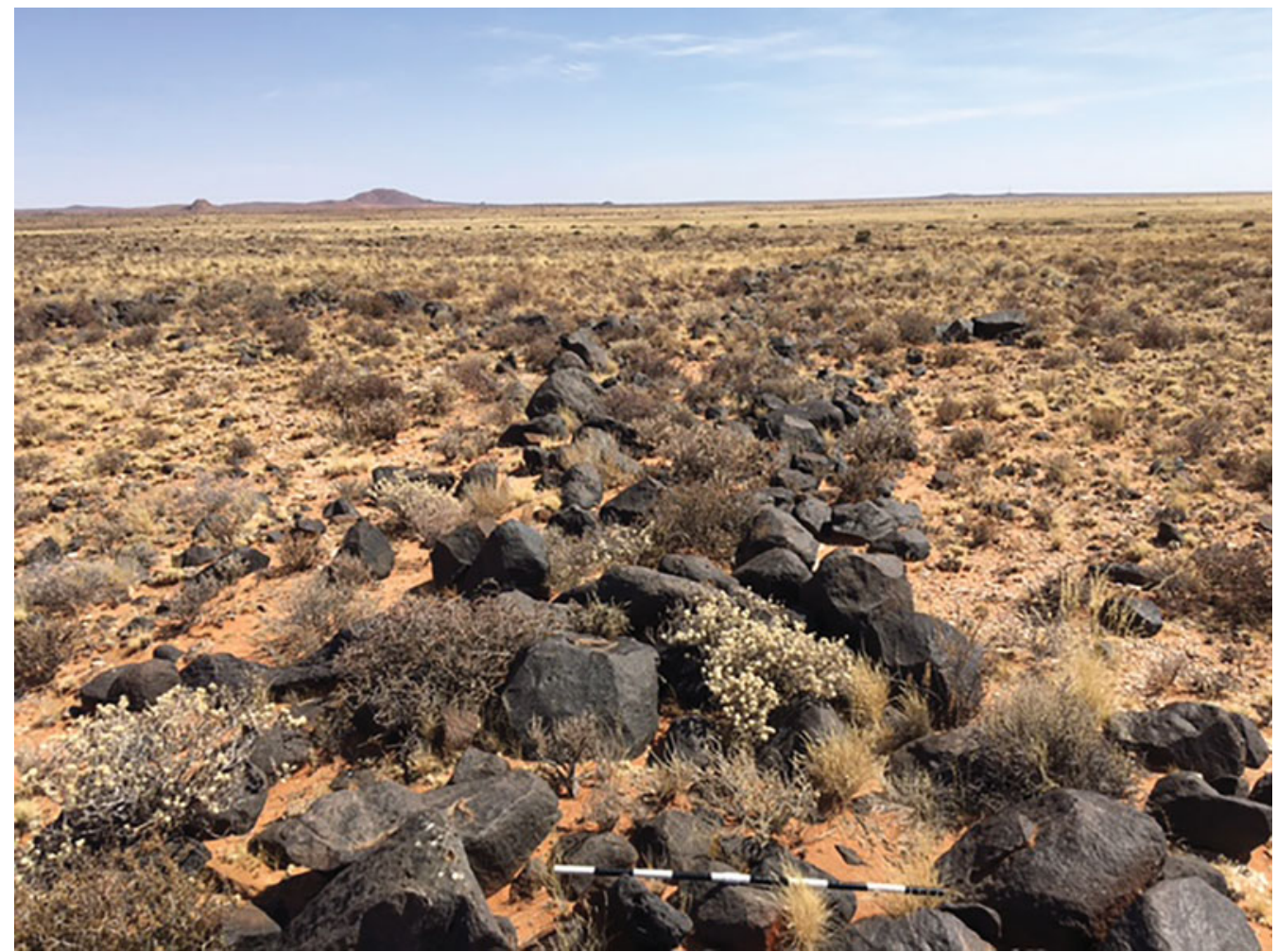

Figure 4. Ground-level photograph of low stone walls (photograph: Jaco van der Walt).

(C) Antiquity Publications Ltd, 2018 

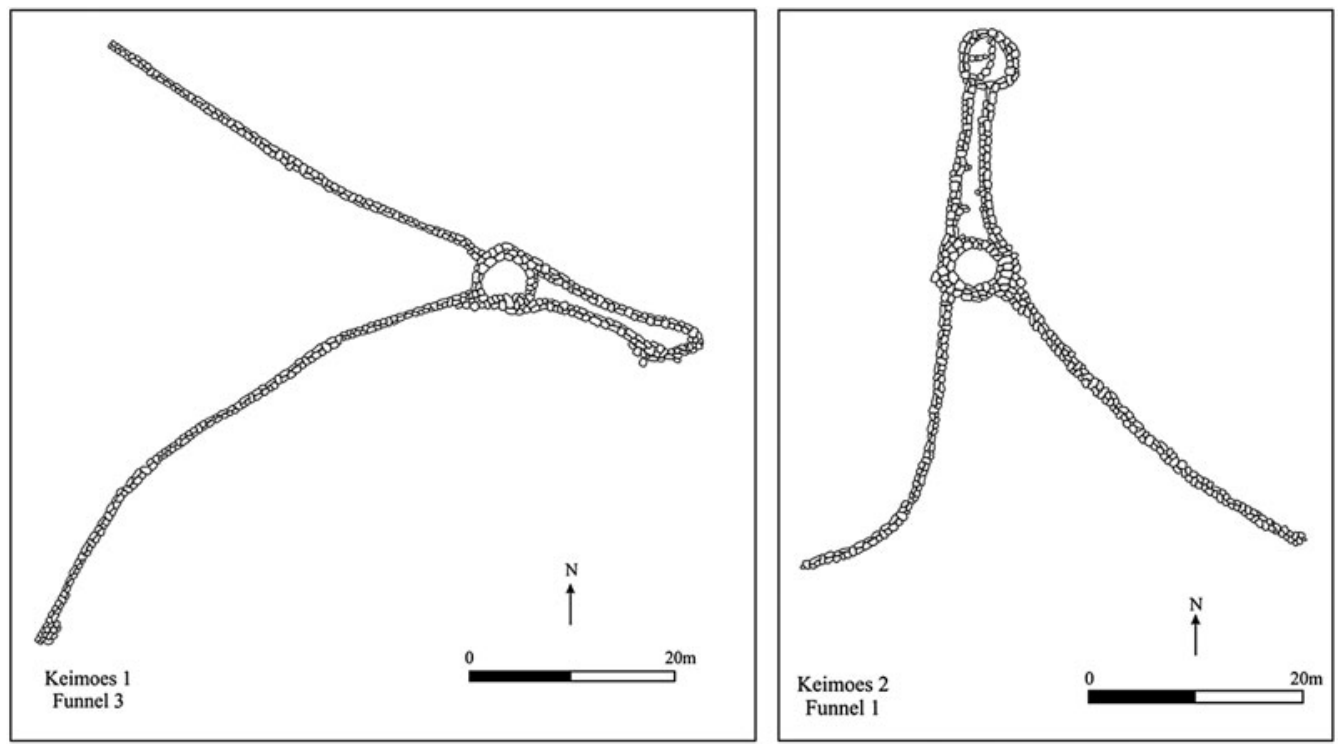

Figure 5. Plan drawing showing stone-built cells of funnel 3 at Keimoes 1 and funnel 1 at Keimoes 2 (drawing: Wendy Voorvelt).

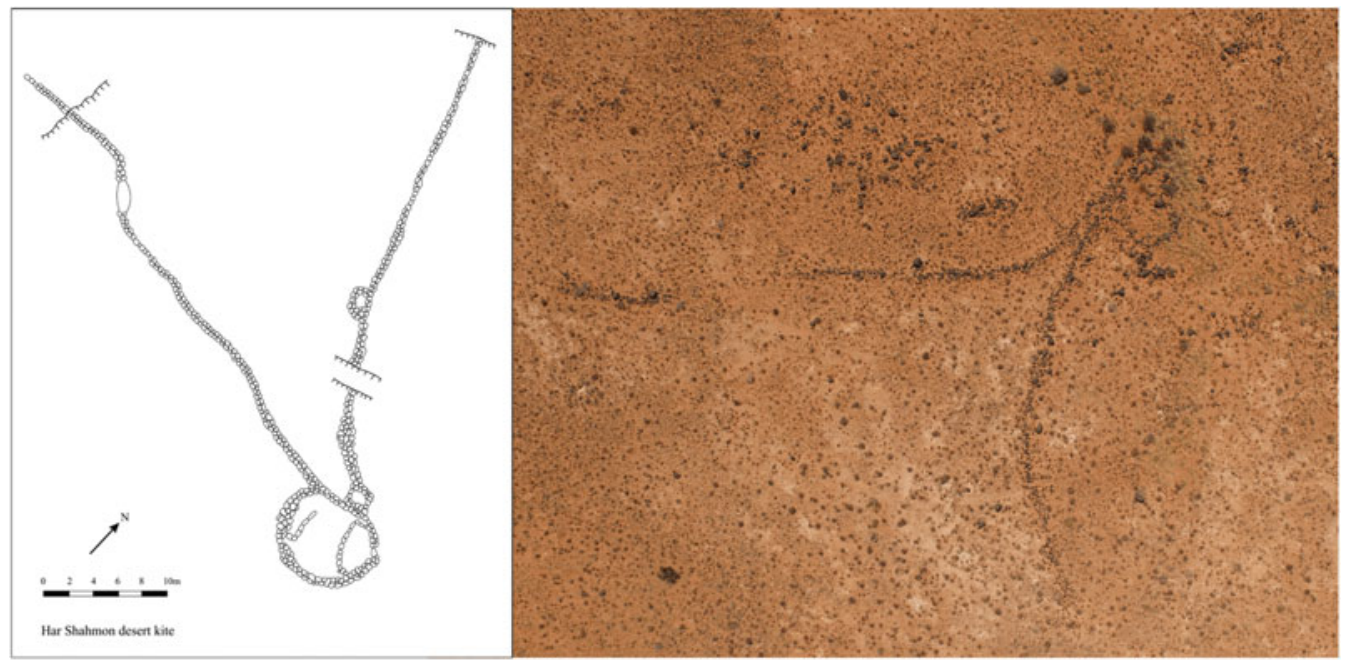

Figure 6. Har Shahmon desert kite on the left (redrawn: Wendy Voorvelt, after Holzer et al. 2010), compared to funnel 1 at Keimoes 1 .

arrangements characteristic of Middle Eastern and Central Asian kites (Echallier \& Braemer 1995).

\section{Current interpretation}

In the absence of dates and cultural material, we can only hypothesise about who built these structures. There is no reason to assume that the kites were constructed by early European settlers. Stone-built structures pre-dating the arrival of Europeans are common (C) Antiquity Publications Ltd, 2018 
in Southern Africa-mostly associated with Iron Age farming communities that settled in South Africa from 1700 years ago (e.g. Huffman 2007). Remains of such settlements are widely distributed in areas with viable arable land and pastures for grazing. No funnelshaped structures have been reported in association with Iron Age sites.

Stone walling associated with a Ceramic Later Stone Age techno-complex (see Lombard et al. 2012) is found at Simon se Klip along the west coast of the Western Cape. From the Seacow River Valley of the Northern Cape Province, Later Stone Age (eleventh century AD) circular, stone-walled stock enclosures are known (Sampson 2010). Stone-built structures associated with the Holocene Later Stone Age (last 12000 years) are rarer and mostly consist of stone circles (e.g. Kinahan 1991; Parsons 2004; Sampson 2010; Sadr 2012; Veldman et al. 2017). The only funnel-shaped structure that we are aware of is at Graafwater, $95 \mathrm{~km}$ to the south-west of the Keimoes kites (Beaumont et al. 1995). There is no record of southern African stone structures pre-dating the Holocene Later Stone Age.

\section{Discussion and conclusion}

Thus far, it is unreasonable to assume that the Keimoes kites were built and/or used by European settlers or Iron Age farming communities, or that they pre-date the Holocene. Based on the widely accepted function for kites as being hunting traps (Holzer et al. 2010), and the ethno-historical records of various kinds of hunting traps used by San huntergatherers, the parsimonious interpretation would be that they were associated with huntergatherer groups. For the last two millennia, however, this landscape was also occupied by Stone Age herding communities (who also hunted); they cannot be discounted as users of these features.

The known distribution and number of recorded kites has increased greatly across the Near East, Arabia, the Caucasus and Central Asia (Barge et al. 2015). The Global Kites project (http://www.globalkites.fr/) was developed to consider kites as a wide-ranging phenomenon, focusing mainly on the Middle East and Central Asia (Crassard et al. 2015). By September 2016, 5210 kite structures had been recorded in the northern hemisphere. Here, we add to this inventory of kite-like structures from a desert-like biome in Southern Africa. These features support notions that they played an important role in animal exploitation in the context of many diverse Old World societies, even though we do not yet understand their exact socio-economic context.

\section{Acknowledgements}

Our research is funded by an African Origins Platform Grant (98815), awarded by the National Research Foundation of South Africa. We thank two reviewers for their input to this text, Simon Todd, for alerting us to these features, and Willem Snyman, who provided access to the sites.

\section{References}

Barge, O., J.É. Brochier \& R. Crassard. 2015. Morphological diversity and regionalisation of kites in the Middle East and Central Asia. Arabian Archaeology and Epigraphy 26: 162-76. https://doi.org/10.1111/aae.12056
Beaumont, P.B., A.B. Smith \& J.C. Vogel. 1995. Before the Einiqua: the archaeology of the frontier zone, in A.B. Smith (ed.) Einiqualand: studies of the Orange River frontier: 236-64. Cape Town: UCT. 
Crassard, R., O. Barge, C.E. Bichot, J.É. Brochier, J. Chahoud, M.L. Chambrade, C. Chataigner, K. Madi, E. RÉgagnon, H. Seba \& E. Vila. 2015. Addressing the desert kites phenomenon and its global range through a multi-proxy approach. Journal of Archaeological Method and Theory 22: 1093-121. https://doi.org/10.1007/s10816-014-9218-7

Echallier, J.C. \& F. Braemer. 1995. Nature et fonction des 'desert kites': donnees et hypotheses nouvelles. Paleorient 21: 35-63.

https://doi.org/10.3406/paleo.1995.4608

Holzer, A., U. Avner, N. Porat \& L.K. Horwitz. 2010. Desert kites in the Negev Desert and northeast Sinai: their function, chronology and ecology. Journal of Arid Environments 74: 806-17. https://doi.org/10.1016/j.jaridenv.2009.12.001

Huffman, T.N. 2007. Handbook to the Iron Age: the archaeology of pre-colonial farming societies in Southern Africa. Pietermaritzburg: University of KwaZulu-Natal Press.

Kinahan, J. 1991. Pastoral nomads of the central Namib Desert: the people that time forgot. Windhoek: Namibia Archaeological Trust and New Namibia Books.
Lombard, M., L. Wadley, J. Deacon, S. Wurz, I. Parsons, M. Mohapi, J. Swart \& P. Mitchell. 2012. South African and Lesotho Stone Age sequence updated. The South African Archaeological Bulletin 67(195): 123-44.

Parsons, I. 2004. Stone circles in the Bloubos landscape, Northern Cape. Southern African Humanities 16: 59-69.

SADR, K. 2012. The origins and spread of dry laid, stone-walled architecture in pre-colonial Southern Africa. Journal of Southern African Studies 38: 257-63. https://doi.org/10.1080/03057070.2012.683697

SAmpson, C.G. 2010. Chronology and dynamics of Later Stone Age herders in the Upper Seacow River Valley, South Africa. Journal of Arid Environments 74: 842-48. https://doi.org/10.1016/j.jaridenv.2008.11.001

Veldman, A., I. Parsons \& M. Lombard. 2017. Kuidas spring 1, Namibia: first impressions of a Later Stone Age site complex. South African Archaeological Bulletin 72(205): 60-70. 